\title{
PERANCANGAN MODEL SIMULASI UNTUK MENINGKATKAN OUTPUT PADA DIVISI ASSEMBLY 14 DI PT. PRATAMA ABADI INDUSTRI
}

\author{
${ }^{1}$ Ishak, ${ }^{2}$ Agustina Christiani, ${ }^{3}$ Livia Narda \\ ${ }^{1,2,3}$ Program Studi Teknik Industri, Fakultas Science dan Teknologi \\ Universitas Pelita Harapan Tangerang \\ Jl. MH. Thamrin Boulevard 1100 Lipo Village
}

\begin{abstract}
A b s trak
Industri alas kaki di Indonesia berkembang dengan sangat cepat, hal ini membuat persaingan diantara industri yang sejenis semakin ketat. Un tuk bertahan hidup, sebuah industri harus bisa menjaga dan meningkatkan kepuasan pelanggan dengan cara memenuhi kebutuhan pelanggan. PT. Pratama Abadi Industri adalah salah satu produsen yang berusaha mempertahankan produksinya. Masalah dari perusahaan ini adalah target produksi sebanyak 225 pasang per jam tidak pernah tercapai. Oleh sebab itu, penelitian ini bertujuan untuk memenuhi target tersebut. Hasil dari penelitian ini adalah menambahkan jumlah operator dan mesin untuk mencapai target tersebut.

Keywords : PPH (pairs/person/hour), Simulation Model, Simulation Process.
\end{abstract}

\section{PENDAHULUAN}

Kondisi sepatu di Indonesia saat ini sedang mengalami perkembangan. Perkembangan industri sepatu di Indonesia dapat dibuktikan dari nilai ekspor yang terus meningkat setiap tahunnya serta surplus ekspor industri sepatu selama 5 tahun terakhir dengan rata-rata yang mencapai USD 2 miliar (Kemenperin 2014). Di sisi lain terdapat pula beberapa industri sepatu yang sedang mengalami lesu akibat tidak stabilnya harga bahan baku, ancaman produk sepatu dari cina, serta terutama diakibatkan oleh daya beli masyarakat yang kurang pada produk sepatu yang dihasilkan. Namun berdasarkan data dari BPS (2015), jumlah industri alas kaki, kulit dan barang dari kulit di Indonesia tetap terus mengalami peningkatan, dimana terdapat sebanyak 671 industri pada tahun 2013 dan meningkat menjadi 701 industri pada tahun 2014. Peningkatan jumlah industri tentu membuat persaingan antar industri menjadi semakin ketat. Menurut Jauch dan Glueck (Hidayat 2015), salah satu hal penting yang perlu untuk dilakukan agar dapat tetap bertahan dan bersaing di dunia industri adalah dengan menjaga dan meningkatkan kepuasan konsumen. Salah satu faktor untuk meningkatkan kepuasan konsumen adalah dengan memenuhi permintaan konsumen dalam jumlah yang diinginkan.

PT. Pratama Abadi Industri merupakan salah satu perusahaan manufaktur sepatu olahraga. Perusahaan ini memiliki keinginan untuk tetap dapat bertahan di dunia industri dengan terus meningkatkan target output agar dapat memenuhi permintaan konsumen. Divisi assembly 14 yang menghasilkan model Basic Leather memiliki target output 225 pasang sepatu/jam. Namun sekarang ini rata-rata output aktual pada divisi assembly adalah 122 pasang sepatu/jam. Oleh sebab itu diperlukan suatu solusi agar PT. Pratama Abadi Industri dapat mencapai target output yang ditetapkan, sehingga dapat memenuhi permintaan konsumen dan meningkatkan kepuasan konsumen. Sebelum perbaikan dilakukan, perlu dilakukan simulasi terlebih dahulu. Simulasi ini dilakukan dengan bantuan software Flexsim. Melakukan simulasi pada sistem sekarang akan memperoleh hasil yang mudah untuk dipahami dan dikomunikasikan. Berdasarkan hasil model simulasi sistem sekarang, maka dapat dilakukan identifikasi masalah yang nantinya akan digunakan untuk memberikan solusi dan membuat model simulasi usulan agar dapat mencapai target output. Dengan mensimulasikan usulan perbaikan yang diberikan maka akan mengeliminasi proses trial and error. 


\section{METODE PENELITIAN}

Penelitian pendaluan dilakukan dengan melakukan observasi di PT. Pratama Abadi Industri yang merupakan obyek penelitian untuk mengetahui kondisi pabrik, produk yang dihasilkan, serta proses-proses yang ada di dalam pabrik tersebut. Selain observasi, dilakukan juga wawancara dengan karyawan Industrial Engineering Department untuk dapat memperoleh informasi mengenai kondisi perusahaan. Penelitian pendahuluan ini berguna untuk membantu identifikasi masalah pada tahap selanjutnya.

Berdasarkan penelitian pendahuluan yang dilakukan maka diketahui bahwa divisi assembly 14 di PT. Pratama Abadi Industri belum dapat mencapai target output yang ditetapkan yaitu sebesar 225 pasang sepatu/jam. PT. Pratama Abadi Industri tentu berkeinginan untuk dapat mencapai target output dengan tujuan untuk meningkatkan kepuasan konsumen.

Berdasarkan perumusan masalah yang telah ditetapkan maka dilanjutkan dengan menetapkan tujuan dari penelitian ini agar dapat menyelesaikan permasalahan yang ada. Tujuan penelitian ini adalah membangun model simulasi usulan yang dapat mencapai target output secara efektif dan efisien pada divisi assembly 14 di PT. Pratama Abadi Industri.

Dalam tahap pembangunan model simulasi untuk sistem sekarang terdapat empat tahapan, yaitu pengumpulan data, pengolahan data, pembangunan model dan analisis hasil simulasi untuk sistem sekarang.

Pengumpulan data dilakukan dengan cara observasi langsung, serta melalui wawancara dengan karyawan PT. Pratama Abadi Industri. Data yang dikumpulkan dapat dikategorikan menjadi dua kategori utama yaitu data umum dan data khusus.

Dalam data umum terdapat data primer dan data sekunder, dimana data primer adalah data proses perakitan produk basic leather yang diperoleh melalui observasi langsung di divisi assembly 14 dan wawancara dengan team leader, sedangkan data sekunder yang merupakan data umum adalah data mengenai sejarah perusahaan, visi dan misi, struktur organisasi dan product structure tree basic leather. Sedangkan seluruh data yang tergolong data khusus merupakan data primer yang diteliti secara langsung dan diperoleh melalui wawancara. Data khusus meliputi data jumlah operator dan mesin pada divisi assembly 14, data tata letak stasiun kerja, data waktu antar kedatangan, data waktu siklus proses produksi dan gambaran detail proses perakitan produk basic leather.

Setelah seluruh data khusus terkumpul maka dilanjutkan dengan pengolahan data. Pengolahan data dilakukan untuk membangun model simulasi sistem sekarang dengan beberapa tahapan yaitu uji normal, uji keseragaman dan uji kecukupan untuk data waktu siklus proses perakitan produk basic leather. Setelah semua uji-uji dilakukan, dibuatlah diagram alir yang menunjukkan bagaimana proses produksi di lakukan di perusahaan tersebut.

Pada tahap ini dilakukan pembangunan model untuk dapat merepresentasikan keadaan nyata yang terjadi di divisi assembly 14 dengan menggunakan software Flexsim. Pembangunan model dilakukan berdasarkan hasil pengolahan data yang telah dilakukan.

Hasil dari proses simulasi untuk sistem sekarang yang telah dijalankan akan dianalisis. Analisis dilakukan pada hasil output yang ditunjukkan oleh software Flexsim, yang bertujuan untuk mengetahui masalah atau hal yang menyebabkan tidak tercapainya target output. Pembangunan Model Simulasi Usulan berdasarkan analisis hasil simulasi untuk sistem sekarang maka akan dilakukan perbaikan dan pembangunan beberapa model simulasi usulan. 


\section{HASIL DAN PEMBaHASAN}

\section{Product Structure Tree Basic Leather}

Model basic leather merupakan model basic yang menjadi ciri khas perusahaan ini sehingga permintaan akan produk ini lebih tinggi dibandingkan dengan produk lainnya. Oleh karena itu, tentu perlu dilakukan perbaikan secara terus menerus pada model produk ini sehingga pada penelitian ini, produk yang diamati adalah basic leather. Informasi mengenai produk basic leather dapat dilihat pada gambar berikut :

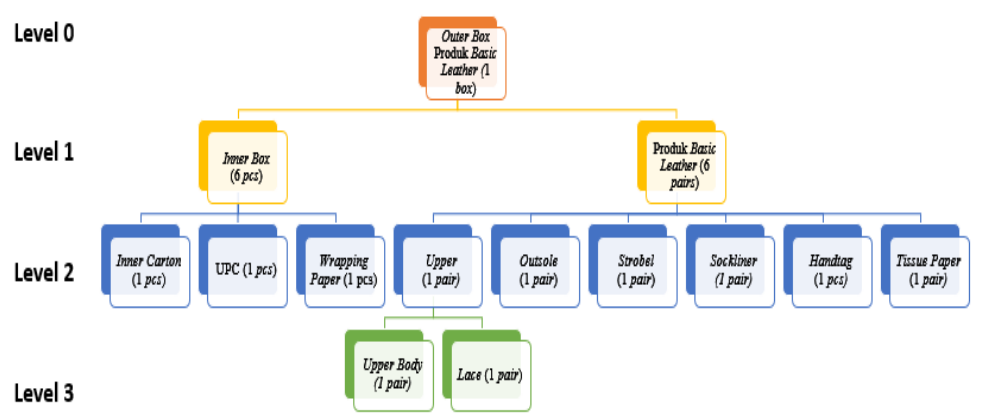

Gambar 1. Product Structure Tree Basic Leather

Proses Perakitan Produk Basic Leather

Divisi assembly 14 terdiri dari beberapa proses yang diperlukan untuk memproduksi produk basic leather. Urutan proses perakitan akan dijelaskan pada tabel 1.

Tabel 1. Proses Perakitan

\begin{tabular}{|c|c|c|}
\hline $\mathrm{NO}$ & Nama Proses & $\begin{array}{ll}\text { Penjelasan } \\
\end{array}$ \\
\hline 1 & BPM Hot \& Cold & $\begin{array}{l}\text { Semua bagian upper sepatu akan melalui proses ini, dimana bagian } \\
\text { belakang dari upper akan dibentuk dengan hot molding yang } \\
\text { kemudian dilanjutkan dengan chilling molding. Proses ini } \\
\text { bertujuan untuk membentuk bagian belakang sepatu sesuai dengan } \\
\text { bentuk kaki manusia. }\end{array}$ \\
\hline 2 & $\begin{array}{l}\text { Strobel Stitching \& } \\
\text { Straightening Bar }\end{array}$ & $\begin{array}{l}\text { Bagian upper sepatu akan dijahit dengan strobel menggunakan } \\
\text { mesin jahit. Setelah itu, hasil jahitan akan diperiksa kerapatannya } \\
\text { dengan straight bar. }\end{array}$ \\
\hline 3 & Upper Heating & $\begin{array}{l}\text { Pada proses ini, bagian upper sepatu akan dipanaskan dengan } \\
\text { menggunakan mesin yang dilengkapi dengan conveyor. }\end{array}$ \\
\hline 4 & $\begin{array}{l}\text { Rotary Toe Box } \\
\text { RE-Activation }\end{array}$ & $\begin{array}{l}\text { Bagian depan pada upper sepatu akan dibentuk dengan } \\
\text { menggunakan mesin yang dilengkapi dengan molding bagian } \\
\text { depan sepatu pada suhu 80-900C yang dilanjutkan dengan } \\
\text { memasukkan laste ke sepatu namun secara asal (laste belum } \\
\text { masuk secara rapi ke sepatu). }\end{array}$ \\
\hline 5 & $\begin{array}{l}\text { Insert Laste to } \\
\text { Upper }\end{array}$ & $\begin{array}{l}\text { Operator pada proses ini akan memasukkan laste ke dalam sepatu } \\
\text { untuk membentuk sepatu sesuai dengan bentuk kaki manusia dan } \\
\text { memudahkan dalam proses perakitan selanjutnya, seperti pada } \\
\text { proses mengikat tali. }\end{array}$ \\
\hline 6 & Heel Heating & $\begin{array}{l}\text { Bagian belakang atau tumit sepatu akan dipanaskan pada suhu 70- } \\
800 \mathrm{C} \text { dengan tujuan agar bagian belakang sepatu dapat mengikuti } \\
\text { bentuk laste dengan baik. }\end{array}$ \\
\hline 7 & $\begin{array}{l}\text { Press Heel Lasting } \\
\text { \& Hammering } \\
\text { Process }\end{array}$ & $\begin{array}{l}\text { Proses ini menggunakan bantuan mesin untuk menekan heel pada } \\
\text { sepatu dengan laste yang berada di dalam sepatu agar bagian } \\
\text { upper sepatu dapat mengikuti bentuk laste dengan baik. }\end{array}$ \\
\hline 8 & Seat Pounding & $\begin{array}{l}\text { Proses ini memiliki tujuan yang sama dengan proses sebelumnya, } \\
\text { namun penekanan antara laste dengan bagian upper sepatu } \\
\text { dilakukan dari atas. }\end{array}$ \\
\hline
\end{tabular}




\begin{tabular}{|c|c|c|}
\hline 9 & Lace Tightening & $\begin{array}{l}\text { Tali pada bagian upper sepatu akan diikat dengan benar dan } \\
\text { kencang pada proses ini agar sepatu benar-benar mengikuti bentuk } \\
\text { laste. }\end{array}$ \\
\hline 10 & Heating Tunel & $\begin{array}{l}\text { Bagian upper sepatu akan dipanaskan dengan menggunakan mesin } \\
\text { yang dilengkapi dengan conveyor pada suhu } 70-800 \mathrm{C} \text {. }\end{array}$ \\
\hline 11 & $\begin{array}{l}\text { Last Upper Bottom } \\
\text { Profile }\end{array}$ & $\begin{array}{l}\text { Pada proses ini akan dilakukan penekanan kembali antara laste } \\
\text { dengan bagian upper sepatu. }\end{array}$ \\
\hline 12 & MEK Upper & $\begin{array}{l}\text { Strobel pada bagian upper sepatu akan dibersihkan dengan } \\
\text { menggunakan bahan kimia MEK agar tidak ada kotoran yang } \\
\text { menempel pada bagian strobel. }\end{array}$ \\
\hline 13 & $\begin{array}{l}\text { Checking and } \\
\text { Setting Outsole to } \\
\text { Upper }\end{array}$ & $\begin{array}{l}\text { Operator pada proses ini bertugas untuk memeriksa kondisi dan } \\
\text { ukuran outsole. }\end{array}$ \\
\hline 14 & Heel Gauge & $\begin{array}{l}\text { Bagian belakang atau tumit sepatu akan ditandai untuk } \\
\text { memudahkan proses selanjutnya dengan menggunakan alat bantu } \\
\text { PVC gauge. }\end{array}$ \\
\hline 15 & $\begin{array}{l}\text { Gauge Marking } \\
\text { Upper }\end{array}$ & $\begin{array}{l}\text { Dimulai dari proses ini, bagian upper dan outsole sepatu akan } \\
\text { diproses sebagai satu kesatuan. Proses ini menandai bagian upper } \\
\text { berdasarkan outsole dengan ukuran yang sesuai. }\end{array}$ \\
\hline 16 & $\begin{array}{l}\text { Buffing Upper \& } \\
\text { Brussing }\end{array}$ & $\begin{array}{l}\text { Pada proses ini, bagian upper akan dikikis dengan menggunakan } \\
\text { mesin agar memudahkan dalam pengeleman dan agar lem dapat } \\
\text { menempel dengan baik. }\end{array}$ \\
\hline 17 & $\begin{array}{l}\text { Attach Tape on } \\
\text { Outsole Heel } 1\end{array}$ & $\begin{array}{l}\text { Pada proses ini, bagian tumit outsole akan ditempel dengan tape } \\
\text { agar nanti pada saat proses pengeleman bagian outsole yang } \\
\text { tertempel tape tidak terkena lem. }\end{array}$ \\
\hline 18 & $\begin{array}{l}\text { Cementing Dry } \\
\text { Chamber } 1\end{array}$ & $\begin{array}{l}\text { Bagian outsole dan upper akan dipanaskan dengan menggunakan } \\
\text { mesin yang dilengkapi dengan conveyor. Conveyor ini terhubung } \\
\text { terus hingga pada proses attaching upper to outsole. }\end{array}$ \\
\hline 19 & $\begin{array}{l}\text { Primer Midsole \& } \\
\text { Take out Off Tape }\end{array}$ & $\begin{array}{l}\text { Pada proses ini, bagian outsole akan dioleskan lem dan kemudian } \\
\text { operator akan melepaskan double tape yang terdapat pada bagian } \\
\text { tumit di outsole sepatu. }\end{array}$ \\
\hline 20 & Primer Upper & $\begin{array}{l}\text { Pada proses ini, bagian upper akan dioleskan lem sesuai dengan } \\
\text { alur bekas proses buffing. }\end{array}$ \\
\hline 21 & $\begin{array}{l}\text { Cementing Dry } \\
\text { Chamber } 2\end{array}$ & $\begin{array}{l}\text { Bagian outsole dan upper akan dipanaskan dengan menggunakan } \\
\text { mesin yang dilengkapi dengan conveyor. }\end{array}$ \\
\hline 22 & $\begin{array}{l}\text { Attach Tape on } \\
\text { Outsole Heel } 2\end{array}$ & $\begin{array}{l}\text { Pada proses ini, bagian tumit outsole akan ditempel lagi dengan } \\
\text { tape agar nanti pada saat proses pengeleman bagian outsole yang } \\
\text { tertempel tape tidak terkena lem. }\end{array}$ \\
\hline 23 & $\begin{array}{l}\text { Cementing Outsole } \\
\& \text { Take out Off } \\
\text { Tape }\end{array}$ & $\begin{array}{l}\text { Pada proses ini, bagian outsole akan dioleskan lagi dengan lem dan } \\
\text { kemudian operator akan melepaskan double tape yang terdapat } \\
\text { pada bagian tumit di outsole sepatu. }\end{array}$ \\
\hline 24 & Cementing Upper & $\begin{array}{l}\text { Pada proses ini, bagian upper akan dioleskan lagi dengan lem } \\
\text { sesuai dengan alur bekas proses buffing dan primer upper. }\end{array}$ \\
\hline 25 & $\begin{array}{l}\text { Cementing Dry } \\
\text { Chamber } 3\end{array}$ & $\begin{array}{l}\text { Bagian outsole dan upper akan dipanaskan dengan menggunakan } \\
\text { mesin yang dilengkapi dengan conveyor. }\end{array}$ \\
\hline 26 & $\begin{array}{l}\text { Attaching Upper to } \\
\text { Outsole }\end{array}$ & $\begin{array}{l}\text { Proses ini menggunakan tenaga manusia untuk menyatukan antara } \\
\text { upper dengan outsole dengan menekan bagian outsole terhadap } \\
\text { upper. }\end{array}$ \\
\hline 27 & Full Press & $\begin{array}{l}\text { Proses ini bertujuan untuk menekan antara outsole dengan upper } \\
\text { menggunakan mesin agar sepatu lebih kuat dan tidak mudah lepas. }\end{array}$ \\
\hline 28 & Chill & $\begin{array}{l}\text { Pada proses ini, sepatu akan didinginkan pada suhu -50C agar lem } \\
\text { pada sepatu menjadi keras dan dapat terbentuk sempurna. }\end{array}$ \\
\hline 29 & Cleaning outsole & $\begin{array}{l}\text { Operator pada proses ini bertugas untuk membersihkan bagian } \\
\text { outsole sepatu dari spidol yang digunakan pada proses gauge } \\
\text { marking upper dengan menggunakan sikat dan air. }\end{array}$ \\
\hline 30 & $\begin{array}{l}\text { Rotary Natural } \\
\text { Conditioning }\end{array}$ & $\begin{array}{l}\text { Sepatu akan dibiarkan pada suhu ruangan untuk menjadikan suhu } \\
\text { sepatu menjadi normal dengan menggunakan mesin yang } \\
\text { dilengkapi dengan conveyor. }\end{array}$ \\
\hline
\end{tabular}




\begin{tabular}{|c|c|c|}
\hline 31 & Loosening Lace & $\begin{array}{l}\text { Operator pada proses ini bertugas untuk melonggarkan tali pada } \\
\text { sepatu. }\end{array}$ \\
\hline 32 & $\begin{array}{l}\text { Delasting \& } \\
\text { Cleaning Laste }\end{array}$ & $\begin{array}{l}\text { Operator pada proses ini bertugas untuk melepaskan laste dari } \\
\text { sepatu. }\end{array}$ \\
\hline 33 & Bod Gap Repair & $\begin{array}{l}\text { Pada proses ini, operator akan menggunakan lem untuk menutupi } \\
\text { gap yang ada antara outsole dengan upper. }\end{array}$ \\
\hline 34 & $\begin{array}{l}\text { Press Logo } \\
\text { Sockliner }\end{array}$ & $\begin{array}{l}\text { Pada proses ini, operator akan melakukan press logo pada } \\
\text { sockliner. }\end{array}$ \\
\hline 35 & $\begin{array}{l}\text { H.M Roll Sockliner } \\
\text { \& Insert Sockliner }\end{array}$ & $\begin{array}{l}\text { Operator pada proses ini bertugas untuk roll sockliner pada mesin } \\
\text { untuk memberikan lem pada sockliner, kemudian memasukkan } \\
\text { sockliner ke dalam sepatu. }\end{array}$ \\
\hline 36 & Sockliner Pressing & $\begin{array}{l}\text { Proses ini bertujuan untuk menekan antara sockliner dengan sepatu } \\
\text { agar tidak mudah lepas. }\end{array}$ \\
\hline 37 & Heel Colar Shape & $\begin{array}{l}\text { Proses ini bertujuan untuk membentuk bagian belakang atau tumit } \\
\text { sepatu dengan menggunakan mesin yang dilengkapi dengan hot } \\
\text { molding dan cold molding. }\end{array}$ \\
\hline 38 & Cleaning Shoes & $\begin{array}{l}\text { Operator pada proses ini bertugas untuk membersihkan sepatu dari } \\
\text { berbagai noda dan dari benang kecil yang ada pada bagian upper } \\
\text { sepatu. }\end{array}$ \\
\hline 39 & $\begin{array}{l}\text { Controlling Quality } \\
1\end{array}$ & $\begin{array}{l}\text { Operator pada proses ini bertugas untuk memeriksa dan } \\
\text { memastikan bahwa sepatu dalam kondisi baik. }\end{array}$ \\
\hline 40 & $\begin{array}{l}\text { Insert Tissue Paper } \\
\& \text { Reset Lace }+ \\
\text { Handtag }\end{array}$ & $\begin{array}{l}\text { Pada proses ini, operator memasukkan tissue paper kedalam } \\
\text { sepatu, yang kemudian dilanjutkan dengan mengikat tali sepatu } \\
\text { dengan benar dan memasangkan handtag pada sepatu. }\end{array}$ \\
\hline 41 & $\begin{array}{l}\text { Controlling Quality } \\
2\end{array}$ & $\begin{array}{l}\text { Opeator pada proses ini bertugas untuk memeriksa dan } \\
\text { memastikan bahwa kualitas sepatu baik. }\end{array}$ \\
\hline 42 & $\begin{array}{l}\text { Folding Inner Box } \\
\& \text { Attach UPC }\end{array}$ & $\begin{array}{l}\text { Pada proses ini, operator bertugas untuk melipat inner box dan } \\
\text { menempelkan UPC pada box untuk nantinya dapat discan. }\end{array}$ \\
\hline 43 & $\begin{array}{l}\text { Wrapping Shoes \& } \\
\text { Scanning Box }\end{array}$ & $\begin{array}{l}\text { Pada proses ini, operator bertugas untuk memasukkan sepatu ke } \\
\text { dalam inner box dengan dilapisi oleh wrapping paper. Setelah itu, } \\
\text { operator bertugas untuk scanning UPC agar dapat mengetahui } \\
\text { jumlah output yang dihasilkan dalam } 1 \text { jam. }\end{array}$ \\
\hline 44 & Detecting Metal & $\begin{array}{l}\text { Proses ini menggunakan mesin yang dapat memeriksa keberadaan } \\
\text { metal pada sepatu agar sepatu bebas dari bahan metal. }\end{array}$ \\
\hline 45 & Packing & $\begin{array}{l}\text { Pada proses ini, operator bertugas untuk packing } 6 \text { buah inner box } \\
\text { dalam } 1 \text { outer box. }\end{array}$ \\
\hline
\end{tabular}

Sedangkan waktu Siklus dari setiap proses dapat dilihat pada tabel 2.

Tabel 2. Waktu Siklus Dari Setiap Proses

\begin{tabular}{|l|l|c|c|}
\hline No & Proses & Wkt Siklus (s) & Std Dev (s) \\
\hline 1 & BPM Hot \& Cold & 24,5 & 1,73 \\
\hline 2 & Strobel Stitching \& Straightening Bar & 36,4 & 2,88 \\
\hline 3 & Upper Heating & 15 & 0 \\
\hline 4 & Rotary Toe Box RE-Activation & 12,77 & 1,21 \\
\hline 5 & Insert Laste to Upper & 17,93 & 0,28 \\
\hline 6 & Heel Heating & 15 & 0 \\
\hline 7 & Press Heel Lasting \& Hammering Process & 16,94 & 0,31 \\
\hline 8 & Seat Pounding & 20,78 & 0,74 \\
\hline 9 & Lace Tightening & 38,85 & 1,25 \\
\hline 10 & Heating Tunel & 12,35 & 0 \\
\hline 11 & Last Upper Bottom Profile & 10,85 & 0,84 \\
\hline 12 & MEK Upper & 14,45 & 1,55 \\
\hline 13 & Checking and Setting Outsole to Upper & 12,34 & 1,32 \\
\hline 14 & Heel Gauge & 15,65 & 1,55 \\
\hline 15 & Gauge Marking Upper & 23,55 & 1,34 \\
\hline 16 & Buffing Upper \& Brussing & 75,98 & 1,5 \\
\hline 17 & Attach Tape on Outsole Heel 1 & 24,81 & 1,08 \\
\hline
\end{tabular}




\begin{tabular}{|l|l|c|c|}
\hline 18 & Cementing Dry Chamber 1 & 23,08 & 0 \\
\hline 19 & Primer Midsole \& Take out Off Tape & 27,32 & 1,04 \\
\hline 20 & Primer Upper & 48,44 & 0,75 \\
\hline 21 & Cementing Dry Chamber 2 & 23,08 & 0 \\
\hline 22 & Attach Tape on Outsole Heel 2 & 27,81 & 1,93 \\
\hline 23 & Cementing Outsole \& Take out Off Tape & 29,2 & 1,64 \\
\hline 24 & Cementing Upper & 45,61 & 1,74 \\
\hline 25 & Cementing Dry Chamber 3 & 23,08 & 0 \\
\hline 26 & Attaching Upper to Outsole & 75,1 & 1,93 \\
\hline 27 & Full Press & 21,26 & 0,93 \\
\hline 28 & Chill & 12,35 & 0 \\
\hline 29 & Cleaning outsole & 19,59 & 0,37 \\
\hline 30 & Rotary Natural Conditioning & 12,35 & 0 \\
\hline 31 & Loosening Lace & 17,41 & 1,88 \\
\hline 32 & Delasting \& Cleaning Laste & 11,42 & 0,4 \\
\hline 33 & Bod Gap Repair & 16,65 & 2,44 \\
\hline 34 & Press Logo Sockliner & 15,11 & 1,06 \\
\hline 35 & H.M Roll Sockliner \& Insert Sockliner & 13,52 & 0,83 \\
\hline 36 & Sockliner Pressing & 10,54 & 0,58 \\
\hline 37 & Heel Colar Shape & 10,07 & 0,64 \\
\hline 38 & Cleaning Shoes & 17,24 & 2,6 \\
\hline 39 & Controlling Quality 1 & 20,11 & 3,15 \\
\hline 40 & Reset Lace + Insert Tissue Paper and Handtag & 42,51 & 3,61 \\
\hline 41 & Controlling Quality 2 & 18,4 & 2,38 \\
\hline 42 & Folding Inner Box \& Attach UPC & 13,1 & 0,87 \\
\hline 43 & Wrapping Shoes \& Scanning Box & 17,04 & 1,57 \\
\hline 44 & Detecting Metal & 45,03 & 0,06 \\
\hline 45 & Packing & & \\
\hline & & & \\
\hline
\end{tabular}

\section{Analisis Hasil Simulasi untuk Sistem Sekarang}

Proses pembangunan model simulasi sistem sekarang dari divisi assembly 14 di PT. Pratama Abadi Industri telah melalui proses verifikasi dan validasi, sehingga dapat disimpulkan bahwa model yang telah dibuat dapat secara tepat merepresentasikan keadaan nyata dari sistem sekarang. Tabel 3 menunjukkan hasil output pada divisi assembly 14 yang dilihat melalui proses wrapping shoes and scanning box selama 8 (delapan) jam kerja, dimana satu kali replikasi merepresentasikan satu jam kerja sehingga dilakukan delapan kali replikasi.

Tabel 3. Hasil Simulasi.

\begin{tabular}{|l|l|}
\hline Replikasi ke- & Output (pairs) \\
\hline 1 & 120 \\
\hline 2 & 126 \\
\hline 3 & 120 \\
\hline 4 & 121 \\
\hline 5 & 121 \\
\hline 6 & 123 \\
\hline 7 & 112 \\
\hline 8 & 121 \\
\hline Rata-rata & $\mathbf{1 2 0 , 5}$ \\
\hline SD & $\mathbf{3 , 9 6}$ \\
\hline
\end{tabular}

Berdasarkan tabel dapat dilihat bahwa nilai rata-rata output yang diperoleh per jamnya adalah 120 pasang sepatu, dengan nilai maksimum dan minimum output per jamnya secara berturut-turut addalah 126 pasang sepatu dan 112 pasang sepatu. Hal ini menjelaskan bahwa model simulasi sistem sekarang memang belum dapat memenuhi target output yang diinginkan yaitu sebesar 225 pasang sepatu/jam. Apabila dilakukan perbandingan antara rata-rata output sistem sekarang dengan target output maka dapat dikatakan bahwa lini sistem sekarang hanya dapat memenuhi 53,33\% dari target output yang diinginkan. Untuk dapat memberikan usulan 
perbaikan maka harus dilakukan identifikasi masalah yang terjadi pada lini sistem sekarang, dimana salah satu caranya adalah melihat \% utilisasi dan \% idle dari masing-masing proses. Data tersebut dapat dilihat pada tabel 4 .

Tabel 4. \% Ultilisasi dan \% idle

\begin{tabular}{|c|c|c|c|}
\hline $\begin{array}{l}\text { Nomor } \\
\text { Proses }\end{array}$ & Proses & \%Utilisasi & \%Idle \\
\hline 1 & BPM Hot \& Cold & 100 & 0 \\
\hline 2 & Strobel Stitching \& Straightening Bar & 72,96 & 27,04 \\
\hline 3 & Upper Heating & 60,19 & 39,81 \\
\hline 4 & Rotary Toe Box RE-Activation & 51,61 & 48,39 \\
\hline 5 & Insert Laste to Upper & 71,99 & 28,01 \\
\hline 6 & Heel Heating & 60,19 & 39,81 \\
\hline 7 & Press Heel Lasting \& Hammering Process & 67,99 & 32,01 \\
\hline 8 & Seat Pounding & 78,23 & 21,77 \\
\hline 9 & Lace Tightening & 73,25 & 26,75 \\
\hline 10 & Heating Tunel & 46,55 & 53,45 \\
\hline 11 & Last Upper Bottom Profile & 40,94 & 59,06 \\
\hline 12 & MEK Upper & 54,39 & 45,61 \\
\hline 13 & Checking and Setting Outsole to Upper & 86,76 & 13,24 \\
\hline 14 & Heel Gauge & 59,03 & 40,97 \\
\hline 15 & Gauge Marking Upper & 44,61 & 55,39 \\
\hline 16 & Buffing Upper \& Brussing & 71,73 & 28,27 \\
\hline 17 & Attach Tape on Outsole Heel 1 & 53,28 & 46,72 \\
\hline 18 & Cementing Dry Chamber 1 & 87,1 & 12,9 \\
\hline 19 & Primer Midsole \& Take out Off Tape & 51,5 & 48,5 \\
\hline 20 & Primer Upper & 91,46 & 8,54 \\
\hline 21 & Cementing Dry Chamber 2 & 87,18 & 12,82 \\
\hline 22 & Attach Tape on Outsole Heel 2 & 52,41 & 47,59 \\
\hline 23 & Cementing Outsole \& Take out Off Tape & 55,05 & 44,95 \\
\hline 24 & Cementing Upper & 86,23 & 13,77 \\
\hline 25 & Cementing Dry Chamber 3 & 87,18 & 12,82 \\
\hline 26 & Attaching Upper to Outsole & 75,1 & 1,93 \\
\hline 27 & Full Press & 21,26 & 0,93 \\
\hline 28 & Chill & 12,35 & 0 \\
\hline 29 & Cleaning outsole & 19,59 & 0,37 \\
\hline 30 & Rotary Natural Conditioning & 12,35 & 0 \\
\hline 31 & Loosening Lace & 17,41 & 1,88 \\
\hline 32 & Delasting \& Cleaning Laste & 11,42 & 0,4 \\
\hline 33 & Bod Gap Repair & 16,65 & 2,44 \\
\hline 34 & Press Logo Sockliner & 15,11 & 1,06 \\
\hline 35 & H.M Roll Sockliner \& Insert Sockliner & 13,52 & 0,83 \\
\hline 36 & Sockliner Pressing & 10,54 & 0,58 \\
\hline 37 & Heel Colar Shape & 10,07 & 0,64 \\
\hline 38 & Cleaning Shoes & 17,24 & 2,6 \\
\hline 39 & Controlling Quality 1 & 20,11 & 3,15 \\
\hline 40 & $\begin{array}{l}\text { Reset Lace + Insert Tissue Paper and } \\
\text { Handtag }\end{array}$ & 42,51 & 3,61 \\
\hline 41 & Controlling Quality 2 & 18,4 & 2,38 \\
\hline 42 & Folding Inner Box \& Attach UPC & 13,1 & 0,87 \\
\hline 43 & Wrapping Shoes \& Scanning Box & 17,04 & 1,57 \\
\hline 44 & Detecting Metal & 12 & 0 \\
\hline 45 & Packing & 45,03 & 4,06 \\
\hline
\end{tabular}

Setelah diperoleh data waktu antar kedatangan masing-masing part dan dilakukan pengujian data waktu proses sehingga diperoleh bahwa seluruh data berdistribusi normal, beserta dengan waktu siklus dan standar deviasi masing-masing proses, maka dapat dilanjutkan kepada proses pembuatan model simulasi dengan menggunakan software Flexsim. 

lima hari.

Tabel 5 menampilkan data output aktual dan data output dari hasil proses simulasi selama

Tabel 5. Data output aktual dan data output dari hasil proses simulasi

\begin{tabular}{|c|c|c|}
\hline Hari ke- & Aktual (pairs) & Simulasi (pairs) \\
\hline 1 & 1097 & 1102 \\
\hline 2 & 1113 & 1101 \\
\hline 3 & 1102 & 1128 \\
\hline 4 & 1103 & 1110 \\
\hline 5 & 1097 & 1109 \\
\hline Total & $\mathbf{5 5 1 2}$ & $\mathbf{5 5 5 0}$ \\
\hline Rata-rata & $\mathbf{1 1 0 2}$ & $\mathbf{1 1 1 0}$ \\
\hline SD & $\mathbf{6 , 5 4}$ & $\mathbf{1 0 , 8 4}$ \\
\hline
\end{tabular}

Berdasarkan data-data di atas, dapat dilihat bahwa proses packing memiliki persentase utilisasi yang paling rendah yaitu sebesar 27,5\% dengan persentase idle paling tinggi yaitu $72,5 \%$. Proses packing memiliki \%utilisasi paling rendah dikarenakan operator pada proses ini banyak melakukan kegiatan menunggu barang input hingga mencapai enam pasang sepatu sehingga apabila waktu antar kedatangan barang input untuk proses ini semakin lama maka idle akan semakin besar. Disisi lain, terdapat dua proses yaitu proses BPM hot \& cold dan proses press logo sockliner yang memiliki persentase utilisasi yang paling tinggi yaitu sebesar $100 \%$ dengan persentase idle yang paling rendah yaitu 0 (nol).

Pada usulan perbaikan akan dilakukan penambahan jumlah mesin dan operator, dikarenakan pada hasil simulasi sistem sekarang dapat dilihat bahwa terdapat jumlah tumpukan bahan baku yang sangat besar pada masing-masing source part. Hal ini dikarenakan kapasitas mesin dari proses pertama sudah tidak mencukupi untuk jumlah barang yang masuk ke dalam lini.

Tabel 6. Data Output Hasil Perbaikan

\begin{tabular}{|c|c|}
\hline Replikasi ke- & Output (pairs) /jam \\
\hline 1 & 228 \\
\hline 2 & 232 \\
\hline 3 & 235 \\
\hline 4 & 232 \\
\hline 5 & 242 \\
\hline 6 & 233 \\
\hline 7 & 233 \\
\hline 8 & 238 \\
\hline Rata-rata & $\mathbf{2 3 4 , 1 3}$ \\
\hline SD & $\mathbf{4 , 2 6}$ \\
\hline
\end{tabular}

\section{Kesimpulan dan Saran}

Berdasarkan analisa di atas, dapat ditarik kesimpulan bahwa ouput dari pabrik tersebut meningkat dari rata-rata 1.110 pasang/hari menjadi 2.106 pasang/hari. Peningkatan tersebut membutuhkan tambahan operator dan mesin seperti pada tabel 7 .

Tabel 7. Jumlah operator dan Mesin

\begin{tabular}{|l|l|l|l|l|}
\hline No & Proses & Keterangan & Jml Opr & Jml Msn \\
\hline 1 & BPM Hot \& Cold & $\begin{array}{l}\text { Operator }+ \\
\text { Mesin }\end{array}$ & 2 & 2 \\
\hline 2 & $\begin{array}{l}\text { Strobel Stitching \& Straightening } \\
\text { Bar }\end{array}$ & $\begin{array}{l}\text { Operator }+ \\
\text { Mesin }\end{array}$ & 3 & 3 \\
\hline 3 & Upper Heating & Mesin & 0 & 2 \\
\hline 4 & Rotary Toe Box RE-Activation & $\begin{array}{l}\text { Operator }+ \\
\text { Mesin }\end{array}$ & 1 & 1 \\
\hline 5 & Insert Laste to Upper & $\begin{array}{l}\text { Operator }+ \\
\text { Mesin }\end{array}$ & 2 & 2 \\
\hline 6 & Heel Heating & Mesin & 0 & 2 \\
\hline
\end{tabular}




\begin{tabular}{|c|c|c|c|c|}
\hline 7 & $\begin{array}{l}\text { Press Heal Lasting \& Hammering } \\
\text { Process }\end{array}$ & $\begin{array}{l}\text { Operator }+ \\
\text { Mesin }\end{array}$ & 2 & 2 \\
\hline 8 & Seat Pounding & $\begin{array}{l}\text { Operator + } \\
\text { Mesin }\end{array}$ & 2 & 2 \\
\hline 9 & Lace Tightening & $\begin{array}{l}\text { Operator + } \\
\text { Mesin }\end{array}$ & 3 & 3 \\
\hline 10 & Heating Tunel & Mesin & 0 & 1 \\
\hline 11 & Last Upper Bottom Profile & $\begin{array}{l}\text { Operator + } \\
\text { Mesin }\end{array}$ & 1 & 1 \\
\hline 12 & MEK Upper & Operator & 2 & 0 \\
\hline 13 & $\begin{array}{l}\text { Checking and Setting Outsole to } \\
\text { Upper }\end{array}$ & Operator & 1 & 0 \\
\hline 14 & Heel Gauge & Operator & 2 & 0 \\
\hline 15 & Gauge Marking Upper & $\begin{array}{l}\text { Operator }+ \\
\text { Mesin }\end{array}$ & 2 & 2 \\
\hline 16 & Buffing Upper \& Brussing & $\begin{array}{l}\text { Operator }+ \\
\text { Mesin }\end{array}$ & 6 & 6 \\
\hline 17 & Attach Tape on Outsole Heel 1 & Operator & 2 & 0 \\
\hline 18 & Cementing Dry Chamber 1 & Mesin & 0 & 2 \\
\hline 19 & Primer Midsole \& Take out Off Tape & Operator & 2 & 0 \\
\hline 20 & Primer Upper & Operator & 4 & 0 \\
\hline 21 & Cementing Dry Chamber 2 & Mesin & 0 & 2 \\
\hline 22 & Attach Tape on Outsole Heel 2 & Operator & 2 & 0 \\
\hline 23 & $\begin{array}{l}\text { Cementing Outsole \& Take out Off } \\
\text { Tape }\end{array}$ & Operator & 3 & 0 \\
\hline 24 & Cementing Upper & Operator & 4 & 0 \\
\hline 25 & Cementing Dry Chamber 3 & Mesin & 0 & 2 \\
\hline 26 & Attaching Upper to Outsole & Operator & 6 & 0 \\
\hline 27 & Full Press & $\begin{array}{l}\text { Operator + } \\
\text { Mesin }\end{array}$ & 2 & 2 \\
\hline 28 & Chill & Mesin & 0 & 1 \\
\hline 29 & Cleaning outsole & Operator & 2 & 0 \\
\hline 30 & Rotary Natural Conditioning & Mesin & 0 & 1 \\
\hline 31 & Loosening Lace & Operator & 2 & 0 \\
\hline 32 & Delasting \& Cleaning Laste & Operator & 1 & 0 \\
\hline 33 & Bod Gap Repair & Operator & 2 & 0 \\
\hline 34 & Press Logo Sockliner & $\begin{array}{l}\text { Operator + } \\
\text { Mesin }\end{array}$ & 1 & 1 \\
\hline 35 & $\begin{array}{l}\text { H.M Roll Sockliner \& Insert } \\
\text { Sockliner }\end{array}$ & $\begin{array}{l}\text { Operator }+ \\
\text { Mesin }\end{array}$ & 1 & 1 \\
\hline 36 & Sockliner Pressing & $\begin{array}{l}\text { Operator + } \\
\text { Mesin }\end{array}$ & 1 & 1 \\
\hline 37 & Heel Colar Shape & $\begin{array}{l}\text { Operator + } \\
\text { Mesin }\end{array}$ & 1 & 1 \\
\hline 38 & Cleaning Shoes & Operator & 2 & 0 \\
\hline 39 & Controlling Quality 1 & Operator & 2 & 0 \\
\hline 40 & $\begin{array}{l}\text { Reset Lace + Insert Tissue Paper } \\
\text { and Handtag }\end{array}$ & Operator & 3 & 0 \\
\hline 41 & Controlling Quality 2 & Operator & 2 & 0 \\
\hline 42 & Folding Inner Box \& Attach UPC & Operator & 1 & 0 \\
\hline 43 & Wrapping Shoes \& Scanning Box & Operator & 2 & 0 \\
\hline 44 & Detecting Metal & Mesin & 0 & 1 \\
\hline 45 & Packing & Operator & 1 & 0 \\
\hline
\end{tabular}

Saran yang diberikan untuk penelitian berikutnya yaitu melanjutkan penelitian dengan memberikan usulan perbaikan dengan cara yang berbeda, misalnya berdasarkan perubahan jarak ataupun layout, dan studi gerakan. 


\section{Daftar Pustaka}

Badan Pusat Statistik. "Jumlah Perusahaan Industri Besar Sedang Menurut SubSektor (2 digit KBLI), 2000-2014," BPS Online. Home page on-line. Available from https://www.bps.go.id/linkTableDinamis/view/id/896; Internet; accessed 22 November 2016.

Beaverstock, Malcolm, Allen Greenwood, Eamonn Lavery, dan William Nordgren. Applied Simulation Modeling and Analysis using Flexsim. USA: Flexsim Software Products, Inc., 2011.

Blanchard, Benjamin S. System Engineering Management. New York: John Wiley \& Sons, Inc., 2008.

Harrell, Charles, Biman K. Ghosh, dan Royce O. Bowden. Simulation Using ProModel. USA: M cGraw-Hill, Inc., 2012.

Harrell, Charles, dan Kerim Tumay. Simulation Made Easy. USA: Ellen Snnodgrass, 1995.

Kementerian Perindustrian Republik Indonesia. "Kemenperin Terus Dorong Pengembangan Industri Alas Kaki Nasional," Kemenperin RI Online. Home page on-line. Available from http://www.kemenperin.go.id/artikel/9745/Kemenperin-Terus-Dorong-PengembanganIndustri-Alas-Kaki-Nasional; Internet; accessed 28 August 2016.

Kumar, S. Anil, dan N. Suresh. Operations Management. New Delhi: New Age International (P) Ltd., 2009.

Muhidin, Sambas Ali. “Tingkat Signifikansi dan Tingkat Kepercayaan," Universitas Pendidikan Indonesia Online. Home page on-line. Available from http://sambas.staf.upi.edu/2013/01/22/tingkat-signifikansi-dan-tingkat-kepercayaan/; Internet; accessed 12 September 2016.

Nurhasanah, Nunung, Faikar Zakky Haidar, Syarif Hidayat, Nida'ul Hasanati, Ajeng Putri Listianingsih, dan Devi Utami Agustini. "Penjadwalan Produksi Industri Garmen dengan Simulasi Flexsim," Jurnal Ilmiah Teknik Industri 2 (2014). [e-journal] http://journal.tarumanagara.ac.id/index.php/jidtind/article/download/1668/1540 (accessed 25 August 2016).

Zhu, X., R. Zhang, F. Chu, Z. He, dan J. Li. "A Flexsim-based Optimization for the Operation Process of Cold-Chain Logistics Distribution Centre," Journal of Applied Research and $\begin{array}{llll}\text { Technology } & 12 & \text { (2014). }\end{array}$ https://www.google.co.id/url?sa=t\&rct=j\&q=\&esrc=s\&source=web\&cd=1\&ved=0ahUKE wiexIDE8MvQAhXDpI8KHd3mCmMQFggcMAA\&url=http\%3A\%2F\%2Fwww.jart.ccad et.unam.mx\%2Fjart\%2Fvol12_2\%2F11_aFle 